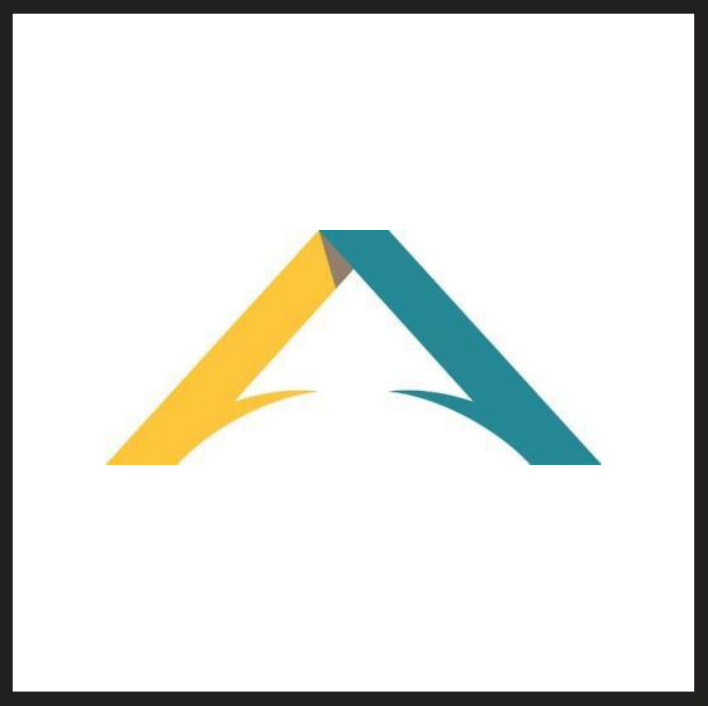

Revista

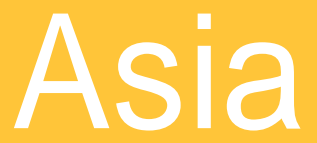

América

Latina

ISSN 2524-9347

Grupo de Estudios sobre Asia y América Latina Instituto de Estudios de América Latina y el Caribe Universidad de Buenos Aires

(c)

EU

DE BA 


\section{ÓSCAR HAHN. IMÁGENES NUCLEARES Y OTROS POEMAS}

Cartonera del Escorpión Azul, 2021. 47 pp.

\section{Rebeca Higuera Vidal}

Universidad Autónoma de Madrid.

rebeca.higuera@uam.es

La radioactividad causada por el armamento nuclear tarda unos veinte mil años en desaparecer, aproximadamente. Por este motivo, el bombardeo de las ciudades de Hiroshima y Nagasaki en 1945, durante la Segunda Guerra Mundial, se considera una de las mayores tragedias que han tenido lugar en la historia moderna. Los acontecimientos se encuentran documentados en muchas fotografías, vídeos y testimonios. Además, el sufrimiento de los supervivientes y las consecuencias medioambientales las tenemos ante nuestros propios ojos. Pero, a pesar de todo, parece que la humanidad no ha aprendido nada, y se dirige irremediablemente hacia su extinción a causa de la fisión del átomo de uranio.

Muchos artistas latinoamericanos han reflexionado en su obra sobre lo ocurrido en Japón y las posibles implicaciones que puede tener para el futuro. Entre ellos, despunta el chileno Óscar Hahn (1938), quien ha trabajado la literatura hispanoamericana desde distintas perspectivas: como profesor en la Universidad de Iowa durante más de treinta años; como ensayista y crítico, cuya labor se encuentra recogida en distintos libros, véase Vicente Huidobro o el atentado celeste (1998), Magias de la escritura (2001) o Palabras sin fronteras (2018); y, sobre todo, como poeta. Hahn ha sido distinguido con varios laureles a lo largo de toda su trayectoria, por ejemplo, con el Premio Casa de América de Poesía por En un abrir y cerrar de ojos en el 2006, con el Premio Nacional de Literatura en Chile en el 2012 o con el XXVII Premio Loewe en el 2014 por Los espejos comunicantes, entre otros galardones. La amenaza nuclear es una constante en toda su obra, desde que apareció entre sus primeras composiciones de Esta rosa negra (1961), hace ya sesenta años. Y con el paso del tiempo, se ha convertido en una de sus mayores obsesiones.

Imágenes nucleares y otros poemas (2021) recoge algunas de las creaciones de Hahn dedicadas a la guerra, al armamento nuclear y a sus secuelas para el planeta y para la civilización. Esta edición de Cartonera del Escorpión Azul otorga a sus poemas un soporte en consonancia con el mensaje de sus versos, cuidando todos los detalles. Por un lado, los libros son fabricados a mano y con materiales reciclados, lo que hace cada ejemplar único. Además, los poemas están acompañados por las ilustraciones de Manolo Mareos; y, por otro lado, la selección y la introducción están a cargo de Sergio Laignelet. Gracias a su trabajo, 
el volumen le permite al lector transitar por toda la obra de Hahn. En primer lugar, se encuentran los poemas reunidos con el título de «Imágenes nucleares», que corresponden a sus comienzos poéticos. Estas composiciones pueden leerse de manera independiente o como un poema extenso, cuya disposición por números de tres cifras describe los horrores vividos en Hiroshima («444. Visión de Hiroshima») y Nagasaki («555. El muerto en Nagasaki») como un descenso a los infiernos, provocado por el apocalipsis nuclear, que finaliza en una indolente partida de azar entre los dioses («666. Reencarnación de los carniceros»). Y después se halla la sección «Otros poemas», formada por las composiciones seleccionadas entre los libros más recientes de Hahn, como Pena de vida del 2008 («Mar y cielo» o «Retrato de una Familia Iraquí»), La primera oscuridad del 2011 («El incendio» $\mathrm{O}$ «Revelación») o el ya mencionado Los espejos comunicantes («Vals de Santiago» o «Guerra sucia»). El volumen incluye también un poema inédito, cedido por el autor para esta edición («Canción del sin con qué»), y un autógrafo de Hahn («En la tumba del soldado desconocido»).

Cartonera del Escorpión Azul acerca así a España a uno de los poetas más importantes del panorama iberoamericano actual. Su iniciativa cuenta con otros títulos, como Voces de un cuerpo de Giovanni Collazos (con nota de Cristina Elena Pardo y fotografías de Jorge Coco Serrano), y los más recientemente publicados: Din don y más hortensias azuis de Luz Pichel (ilustrado por Anxo Pastor) y 999 palabras de Víktor Gómez (con nota de Lola Andrés y Benito del Pliego e ilustraciones de Enrique Cabezón).

La guerra es un tema de la literatura universal. Todas las culturas poseen un modelo que forma parte de su tradición. En Occidente, por ejemplo, la poesía épica mitifica conflictos bélicos, a grandes rasgos, desde La Ilíada, donde las deidades desencadenan un conflicto gracias al que sus protagonistas se convierten en héroes conocidos hasta la actualidad. Para Hahn, las deidades juegan cruelmente con el destino, al margen de los acontecimientos: «Y vi los carniceros al tercer día; / rojos como una sangre avergonzada, / jugaban con siete dados hechos de fuego, / pétreos como los dientes del silencio» (p. 15); y la guerra nunca es una hazaña que concede la inmortalidad, sino todo lo contrario. Sus poemas están poblados por los fantasmas de las víctimas, obligados a vagar entre escombros. Aunque la tragedia sea colectiva, la muerte es una experiencia individual: «Cada una de las víctimas / que se desintegraron en Hiroshima / murió su propia muerte» (p. 28). Nunca se desvelan nombres propios y su recuerdo se pierde, al igual que sus objetos personales: «Todos ellos sonriendo/ desde una foto a medio chamuscar / hallada entre los escombros / de su casa / después del bombardeo» (p. 27).

La búsqueda de saber y trascendencia es inherente también al ser humano. Las buenas intenciones y los descubrimientos científicos pueden acabar malográndose por su propia naturaleza. Así ocurre con la energía nuclear, esa piedra filosofal moderna, que una vez encontrada en el cráneo trepanado de su 
creador, muestra grandes propiedades benéficas, pero también revela su inmenso peligro contaminante, impidiendo la vida: «transmuta el plomo en oro y los metales / preciosos en uranio radiactivo / Lo que viene después es la diabólica / reacción en cadena de sus átomos / Ya desató el infierno de Hiroshima / ya arrasó la ciudad de Nagasaki / si se activa otra vez devastará / al fuego al agua al aire y a la tierra» (p. 39).

Una vez los humanos se hayan extinguido, quizá nazca una nueva civilización, marcada en su cuerpo por la radiactividad. Sus antepasados, entre los que se identifica Hahn, son los profetas de un nuevo Ares: «Los mutantes me mirarán con asombro / y entrarán de nuevo en la caverna / para adorar la imagen de su dios / que es un hongo atómico (p. 35). Y la naturaleza también renacerá. La falta de luz solar provocará que las plantas hagan cálculos matemáticos, resuelvan teoremas e invadan las ciudades, acabando con los mutantes: «Si los despojos de los dormidos /pudieran pensar / sabrían que fueron devorados / por manadas de plantas inteligentes» (p. 32).

En conclusión, la cuidada edición de Imágenes nucleares y otros poemas que publica Cartonera del Escorpión Azul potencia el mensaje ético de los versos de Óscar Hahn ofrece un recorrido por toda la obra del poeta chileno y alberga en sus páginas una de las miradas más lúcidas que puedan encontrarse en la poesía hispanoamericana actual. Al pronunciarse sobre la guerra y lo nuclear y al imaginar ese nuevo mundo poblado por mutantes, Hahn anticipa las probables consecuencias de la radiactividad a la vez que consigue dar una voz sumamente original a sus víctimas. 

